\title{
Urban resilience building in modern development: a case of Phnom Penh City, Cambodia
}

\author{
$\underline{\text { Sothun Nop }}^{1,2}$ and Alec Thornton ${ }^{1,3}$
}

\begin{abstract}
Although the process of building urban resilience is increasingly and globally promoted, we consider this concept, and the approaches to achieve it, as particularly challenging for cities in developing countries. We argue that current market-oriented processes of urban upgrading reflect a revival of modernization concepts that, as a consequence, is deepening inequality and limiting adaptive capacities of people to cope with livelihood disruptions resulting from natural disasters and climate change. Efforts in building urban resilience thus become more difficult for marginalized urban dwellers. We explored current climate-related hazards and their impacts on urban livelihoods in selected urban communities in the city of Phnom Penh. We adopted a mixed methods approach, and our key findings revealed limited local government attention to improving infrastructure and a lack of commitment to assist vulnerable urban poor communities to build resilience to natural shocks. Policy recommendations include supporting livelihood improvement programs, addressing land tenure insecurity, and improving basic infrastructure in informal settlements.
\end{abstract}

Key Words: adaptation mechanism; climate-related risk; livelihoods; modern development; urban resilience; urban upgrading

\section{INTRODUCTION}

Building urban resilience is on the agenda for urban planners and policy makers in many cities in an era of increasing environmental hazards, urbanization, and rising population density (Coaffee and Lee 2016, Meerow et al. 2016). Although the precise meaning of urban resilience remains unclear, it is commonly viewed as a process of enhancing the capacity of urban systems to resist a wide range of shocks and stresses (Davoudi et al. 2012). Meerow et al. (2016) explain "urban resilience" as an urban system that can maintain or rapidly return to desired functions in the face of a disturbance, adapt to change, and quickly transform socialecological systems that limit current or future adaptive capacity. We will critically assess the Cambodian government's aims for modern urban development, which seek to build resilient socialecological systems through enhancing the adaptive capacity of individuals and institutions (National Council for Sustainable Development, Royal Government of Cambodia, Phnom Penh Capital Hall, Global Green Growth Institute, and International Centre for Environmental Management 2016).

Kumar (2015) and Friend et al. (2013) argue that improving understanding of existing urban vulnerabilities enables key stakeholders to formulate efficient and effective responses to catastrophes. This corresponds with the idea of Liao (2012) and Mehmood (2016), who view learning by doing as key for resilience building. In developing countries, some governments seek urban industrialization as a strategy to modernize and strengthen urban capacity (Pickles and Smith 2005, Phillips 2011). As Marsh (2014) argues, this "revival" is seen in processes of enhancing industrialization in developing countries for economic development. Phillips (2011) similarly argues that modernization vigorously influences the agenda of contemporary development that is perceived as a process of social change. Aspects of economic, social, and cultural change and progress are open and flexible for improving levels of wealth and living standards of local people to "catch up" with more developed societies.
We argue that current market-oriented processes of urban upgrading $^{[1]}$ reflect a revival of modernization concepts that, as a consequence, is deepening inequality and limiting adaptive capacities of people to cope with livelihood disruptions resulting from natural disasters and climate change. Efforts to build urban resilience thus become more difficult for marginalized urban dwellers. In the context of Cambodia, some research has explored potential urban disaster risks and coping mechanisms at the community level (Denney 2016, Diepart et al. 2016, Flower et al. 2018). This research is needed to understand adaptation strategies of the urban poor and to what extent their efforts are thwarted by modern development in Phnom Penh. Comprehensive understanding of the extent of risks, vulnerability, and local capacity is important for designing strategies for "disaster risk reduction"(DRR; Desouza and Flanery 2013, Flower et al. 2018). We will analyze urban resilience building in Phnom Penh, focusing on the effectiveness of adaptation strategies and key elements and actors influencing adaptive capacity in urban communities. With Phnom Penh City attempting to modernize to build resilience, we aim to contribute empirical evidence to wider debates on these processes in a developing country context. Research findings will benefit future studies and inform urban planners, policy makers, and development practitioners concerned with urban resilience building.

The revival of modernization theory in contemporary urban
development
Urbanization and industrialization are linked as "indisputable"
processes of modernization (Bidandi and Williams 2017, Sayan
2017, McGill 2018). Although heavily criticized, the central ideas
of modernizing as a staged process, moving from traditional to
modern, persist in the literature (Kilminster 2007). Marsh (2014)
noted that in modernized urban societies, people often have better
"self-flexibility" to anticipate climate threats and adopt measures
to mitigate them. In non-Western countries, researchers view
"multiple modernities" and justify "new directions" for a


revitalized modernization, to account for anomalies that could not be explained with the original theory (Jha et al. 2013, Marsh 2014).

Revitalization of modernization concepts is reflected in processes of enhancing industrialization in developing countries for economic development (Marsh 2014). Marsh (2014) also notes that nonmonetized economic sectors, energy consumption, average life expectancy, average education level, and percentage of telephones are used to determine levels of modernization. This justification reflects what Kim (2017) called "alternative modernity," which is viewed as a nonfixed but dynamically emergent phenomenon influenced by current social, cultural, political, and economic contexts. Revitalized modernization is also seen through the process of ecological modernization, criticized as economic "greenwashing," which focuses on improving environmental governance in dealing with environmental issues resulting from contemporary development activities (Inglehart 2014, Lockie 2015). An ecological modernization perspective emphasizes a closed connection between ecology and economic growth and industrial development. It also suggests that social-ecological challenges can be addressed through achieving goals of modern development and environmental improvement by encouraging technological innovation and new forms of economic and market agents (Jänicke 2008, Hobson and Lynch 2018).

From a modernization perspective, urbanization has played a crucial role in transforming economic and social factors (Marsh 2014), but also in creating socio-spatial inequality. The Sustainable Development Goals (SDGs), specifically SDG 11, focus on making cities more inclusive, safe, and resilient (United Nations Human Settlements Programme [UN Habitat] 2016, United Nations 2017). Sustainable urbanization presupposes that the right to development of low-income and middle-income countries can be realized and that the needs of urban poor communities can be fulfilled (UN Habitat 2016). In practice, policies for meeting these objectives often fall short, resulting in a loss of money, time, and effort and frustration toward achieving these goals (Hassan and Lee 2015).

\section{Urban resilience in informal urban settlements}

Rapid urbanization presents several cross-sectoral policy challenges, including increased squatter areas, insecure land tenure, insufficient service provision, and environmental degradation (United Nations 2014, Neef and Singer 2015). Jabareen (2015) argues that although many cities have plans to overcome these issues, they have predominantly applied traditional approaches and ignored the predicted threats, uncertainties, and vulnerabilities correlated with climate change. Consequently, lives and livelihoods in urban poor communities, especially informal settlements, are at risk because of limited adaptive capacity (Guild and Matsumoto 2013, Inderberg et al. 2014), exposure to poor environmental quality (Davis 2006, Willis 2011), and ineffective DRR strategies to prepare urban communities to cope with climate change (Birkmann and von Teichman 2010, Flower et al. 2018).

In the case of Cambodia, attempts to build urban resilience can be seen through the Green City Strategic Plan 2016-2025 for transforming Phnom Penh into a clean, green, and sustainable city offering a safe and modern lifestyle to its residents (National
Council for Sustainable Development, Royal Government of Cambodia, Phnom Penh Capital Hall, Global Green Growth Institute, and International Centre for Environmental Management 2016). There are three elements to this strategic plan: inclusive growth, social justice, and environmental stability. Various projects have been designed to implement this plan, while improving urban poor livelihoods. Despite this, the vulnerable conditions of poor communities have not improved (Sahmakum Teang Tnaut [STT] 2018, The World Bank 2018). Consequently, peri-urban dwellers remain vulnerable to flooding, pollution, poor wastewater management, fires, landslides, and storm damage (Denney 2016, STT 2016, Flower et al. 2018). Specifically, urban flooding contains contamination from sewage systems and storm-water runoff, which often contains industrial contaminants and other pollutants (Flower and Fortnam 2015). Because the poor cannot compete in the formal property market (Davis 2006), they often opt to settle on unstable hillsides and floodplains or along polluted streams and rivers, which make them susceptible to diseases and natural disasters (STT 2018).

The previous discussion highlights a disconnect between building urban resilience and the pursuit of urban economic modernization, particularly in urban poor communities that are characterized by low adaptive capacity and vulnerability to disasters (Davis 2006, STT 2018). This urban condition seems to diverge from views on urban resilience, as emphasized by Mehmood (2016), who considers it the formulation of immediate responses to disaster as well as long-term adaptation and mitigation strategies in confronting social, environmental, and economic challenges.

\section{Study area}

Phnom Penh is the capital city of Cambodia and is located in the floodplain areas on the western bank of the Mekong River. The city is surrounded by ring roads, which are built as dikes to protect it from seasonal floods between June and November. Because of rapid urbanization and integration of peri-urban communes in the last decade, the city's area has nearly doubled. Urban expansion is connected to increasing demand for economic investment, especially in the real estate sector. This sector is expected to help drive economic growth and respond to the housing needs of a population that has increased from 1.13 million in 1998 (Trac 2015) to an estimated 2.4 million by 2020 (Japan International Cooperation Agency 2014).

The 2014 National Housing Policy is aimed at ensuring city dwellers have affordable housing, secure land tenure, and access to basic infrastructure and services; however, the implementation of the policy remains slow and ineffective (The World Bank 2018). This may well relate to limitations in finance and coordination between agencies and departments to ensure desired development outcomes. Phnom Penh has the highest rate of land issues (29 cases in 2013) compared with other provinces of Cambodia (NGO Forum on Cambodia 2014). These land conflicts have interconnected with issues of forced eviction affecting thousands of families that have been removed to peri-urban settlements outside the city center (Mgbako et al. 2010). In fulfilling the ambitions of governments and corporations toward "progress," as explained by Brickell et al. (2017), the new resettlement areas are far removed from the city center, which has disrupted livelihoods and negatively affected the well-being of slum 
communities (Connell and Connell 2016). In 2002, about 16,000 people had been displaced from their homes in slum areas as a consequence of the demand for spaces for an "urban revitalization program," announced by the government for rebuilding Phnom Penh as one of Southeast Asia's grandest cities (Olds et al. 2002). These urban upgrading programs displaced hundreds of thousands of families and focused on infrastructure and the development of commercial and modern residential buildings (Brickell 2014, STT 2016).

Forced eviction has been interpreted by affected communities as a sanction from the government and is an ongoing threat facing urban communities (Flower and Fortnam 2015). Forced eviction is a ubiquitous intensification process influenced by neoliberalism (Casolo and Doshi 2013). Critiques of market-oriented neoliberal urban policy making are often ambiguous and less implementable leading to divergence between policy expectations and results (McMichael 2012, Tulumello 2016). As highlighted by Brickell et al. (2017), forced evictions under urban "regeneration" or "beautification" have occurred in many global cities, where the poor are perceived as an "externality" of modern development (McMichael 2012). Although most evicted communities of Phnom Penh have received compensation from the government or investors, it is far below the market value of properties and is insufficient to build adequate housing in the new settlement plots (McFarlane 2012, Connell 2015).

\section{RESEARCH METHOD}

To enhance the validity of the study results, we employed a mixed methods approach, which combined both quantitative and qualitative techniques. This method is suitable to enlarge the scope, extend insights, and improve the analytical power of research of complex human phenomena (Sandelowski 2000). We will cover the discussion of case study design, sampling and data collection techniques, and data analysis methods.

\section{Case study design}

We concentrated in two Sangkats, or communes, of Phnom Penh: Khmuonh, in Khan Saen Sokh, and Kouk Roka, in Khan Praek Phnov. These locations are appropriate because the two Sangkats are located in outer urban areas where urban upgrading activities are assembled. We chose these areas because they are considered vulnerable as a result of communities having very limited access to basic public services, such as clean water, electricity, or waste management systems; job opportunities; and livelihood resources (McFarlane 2012, Flower and Fortnam 2015, The World Bank 2018). Although both areas are geographically located close to natural lakes and canals, these resources are increasingly contaminated from urban-industrial wastewater.

Both Sangkats consist of a mixture of two kinds of villages. Old established villages are those that have been established since the collapse of the Pol Pot regime in 1979. The newly established urban communities were established in the early 2000s, after rapid urbanization had increased and more city land areas were needed for investments. The residents of these villages were relocated from informal or slum communities in the city center through both voluntarily and forced eviction.

\section{Sampling and data collection methods}

Our secondary data concerning topics of urban resilience and modern urban development have been reviewed from journal databases, nongovernmental organizations (NGOs), and government websites. Our primary data were collected from a total of 428 household surveys (Table 1, Fig. 1), where 1 member of each household, i.e., the head of household, was interviewed. The survey participants were selected on a voluntary basis. Closed-ended questionnaires were used for household surveys, and face-to-face interviews were also used for the data collection process. From the questionnaires, respondents were asked to scale ( $1=$ very low to $5=$ very high) levels of climate-related risk and its effects on urban communities, level of effectiveness of their adaptive strategies, or level of external support.

Table 1. Research sample size.

\begin{tabular}{ccccc}
\hline \hline No. & Study Areas & Population† & Sample Size & $\begin{array}{c}\text { No. of } \\
\text { Selected } \\
\text { Villages }\end{array}$ \\
\hline 1 & Khmuonh & 5719 & 207 & 10 out of 13 \\
2 & Kouk Roka & 2928 & 221 & 12 out of 18 \\
& Total & & 428 & 22 \\
\hline
\end{tabular}

'Sources: Councils of Sangkat Khmuonh (2016), Councils of Sangkat Kouk Roka (2016).

Systematic random sampling, in the probability sampling method, was employed for selecting respondents. Every fifth household of the chosen villages was selected for an interview, with consideration of gender balance and a mixture of different household characteristics. Nine undergraduate (year 4) students were recruited and trained by researchers to implement the questionnaire surveys, in the Khmer language. Because of disorganized settlements in peri-urban or informal communities, some inaccuracies could possibly occur in the process of identifying respondents based on the systematic sampling technique. As a strategy to minimize error, enumerators were trained and closely monitored during the research. The qualitative research was composed of 8 focus group discussions (FGDs; 4 in Khmuonh and 4 in Kouk Roka) with a total of 40 participants, who were selected from the convenience sampling technique. However, the FGD participants needed to be the head of household or the elderly who had been living in the communities for more than 5 years. Twelve key informant interviews (KIIs) were conducted with the representatives of government agencies (4), NGOs (4), academia (2), and the private sector (2) through the snowball sampling method. The FGDs and KIIs were semistructured, allowing for more flexibility to explore particular or unexpected themes raised by the respondents (Corbetta 2003, Walliman 2015).

\section{Data analysis}

The quantitative data obtained from the household surveys were processed and analyzed by employing IBM SPSS v.24. Descriptive statistics were used to examine the respondents' socioeconomic characteristics. The Pearson correlation coefficient test was used to observe the connection between level of education and level of income for survey respondents. An independent $t$ test was used to discern if there was significant difference in the perception of respondents between both study areas in term of the levels of risk of climate-related hazards and their impacts on urban livelihoods, level of effectiveness of adaptation strategies, and levels of external support for improving urban communities' adaptive 
Fig. 1. Study areas.
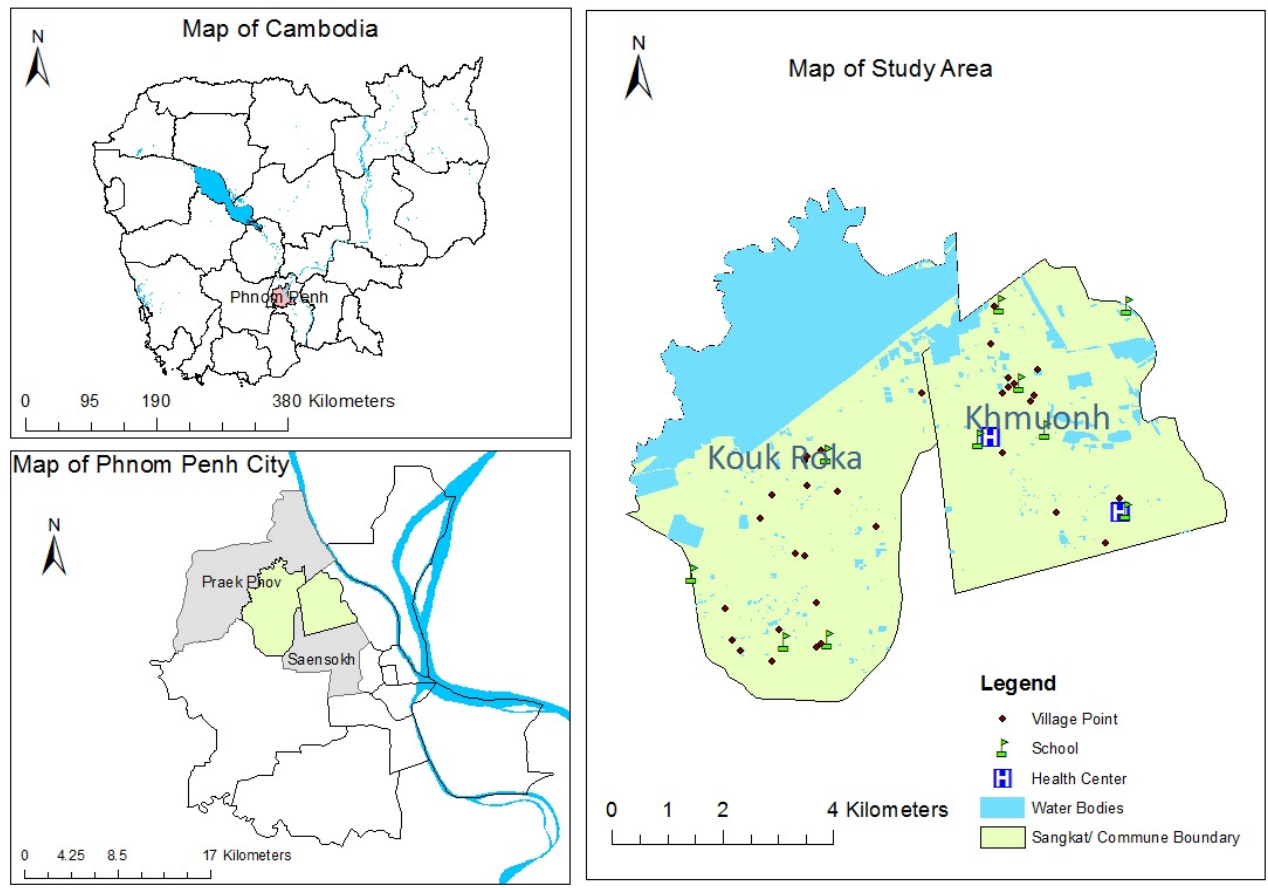

capacity. The weight average index (WAI) was calculated to measure the participants' responses. WAI was measured on a 5point scale $($ very low $=0.00-0.20$, low $=0.21-0.40$, moderate $=$ $0.41-0.60$, high $=0.61-0.80$, and very high $=0.81-1.00)$. This index measured the mean score converted from the questionnaire Likert scale. In the case of a respondent who chose 1 (risk is very low), this answer was equal to a value of 0.20 in WAI, but if the number 5 was selected, then the value was equal to 1.00 in WAI. Also, a chi-square test was used to observe if there was a significant difference in the perception of respondents between both locations in term of types of assistance during the disaster events. Because both study areas are in different Khans with different administrative leadership (governors), it is crucial to examine if communities in both locations have encountered a different level of risks or obtained different adaptive capacities. To execute the tests, a $95 \%$ confidence level, i.e., $e=0.05$, was assumed. Analysis of transcribed qualitative information was facilitated by the use of NVivo (Pro 11), for indexing, sorting, and coding the data, and a thematic analysis tool was applied for structuring the obtained information and selecting quotations for elaboration and justification of quantitative data.

\section{RESULTS AND DISCUSSION}

Socioeconomic factors influencing resilience

The survey results indicate that more women $(75 \%)$ than men participated, because of the latter being away from home for work reasons and women being mainly responsible for household chores and child rearing. The majority of respondents (about $71 \%$ ) were in the age group between 31 and 60 , followed by $<31$ (about 20\%) and $>60$ (about 9\%). Most of them were employed in garment factories and construction firms (41.6\%) and casual employment including taxi driving, laundry, cleaning private houses or companies, shoe polishing and sewing, and rubbish collection $(22 \%)$. About a quarter of respondents were selfemployed, and approximately $10 \%$ had engaged in formal employment, i.e., with companies, the government, and NGOs. Although nearly $54 \%$ of respondents received a primary education and $21 \%$ had attended secondary school, about $16 \%$ were illiterate. A small percentage had achieved high school $(8.2 \%)$ and university ( $1.4 \%$ ) education. Regarding income levels, about $61 \%$ of respondents earned between US\$2000 and US\$4000 per year, whereas about one-third earned less than US\$2000 per year. Only about $8 \%$ had annual incomes greater than US $\$ 4000$. Moreover, a Pearson correlation coefficient test revealed a positive correlation between education and income levels $(r=$ $0.231, P=0.001)$.

About $55 \%$ of respondents spent between US\$2000 and US\$4000 per year, whereas about $43 \%$ spent less than US\$2000 per year, and the rest $(2 \%)$ spent more than US\$4000 per year. These findings indicate that households earning less than US\$2000 spent most of their income, with limited opportunity to save their earnings. As part of their survival strategies, about $59 \%$ of the respondents had received loans for their families' needs. Interview respondents revealed that despite rapid growth of urban upgrading projects, their incomes had slightly improved. The high increase of inflation causes many poor urban dwellers to spend most of their income. Establishing a small business or having a medical emergency represent more immediate needs for funds from microfinance institutions (MFIs) or local lenders. As suggested by Connell (2015) and Flower and Fortnam (2015), 
almost every family relocated to new peri-urban areas has borrowed money from MFIs or private lenders to upgrade their shelters and maintain their livelihood activities.

Among these debtors, only about $19 \%$ are able to return the loan on time, whereas the remaining $81 \%$ have faced difficulties in returning the debt based on the schedule. This has caused anxiety for the urban poor (Connell 2015), because loans of this nature often lead to crippling debt and the confiscation of household assets. This result aligns with findings in the literature indicating that hardships from increasing indebtedness among urban private households in China (Zheng and Deng 2018) and Spain (Di Feliciantonio 2016) are connected to real estate projects and other forms of neoliberal urbanism. Related to this finding, although the Cambodian government's strategies for DRR have concentrated on addressing specific hazards such as river flooding, the complexities of household indebtedness remain overlooked (Flower and Fortnam 2015). Consequently, the resilience of poor households to potential hazard risks has been restricted by the endemic poverty. The evidence reflects low adaptability of urban dwellers because they are less flexible in using their current capacities to select better options for addressing immediate needs and responding to risks. Moreover, a lack of institutional strategies for enhancing the robustness of urban communities limits the potentials of urban communities to build resilience to disturbances.

\section{Risks of climate-related hazards in urban areas}

The independent $t$ test results (Table 2) reveal that heat wave has highly affected the communities in both areas. As suggested by FGDs and KII participants, this is because most of the houses in new established villages are condensed with very few trees or vegetation around them. The walls and rooftops of most houses are built from zinc, and the houses' sizes are relatively too small for the kinds of extended families. An FGD participant stated, "My family has lived in the house with the size of $3.8 \mathrm{~m} \times 5$, which was provided by the investor or government as a compensation for the relocation and there are 9 members in the family, so we have to live in the narrow space like piglets in the cage [...] during strong sunlight or black out, my family members cannot stay in the house, we need to escape to the nearest trees or shadow."

Although the literature is limited highlighting the negative impacts of heat waves in Phnom Penh, we reveal similar impacts on quality of life, especially for those who have fewer resources to adapt, upgrade, and cope with heat impacts (Jabareen 2015). Moreover, urban areas have become warmer because of higher heat absorption and limited cooling systems associated with urban biodiversity and permeable surfaces (Tyler et al. 2010, The World Bank 2011, UN Habitat 2016). This extreme weather has increased the threat of heatstroke in poor urban communities in developing countries, where access to basic public services, such as safe drinking water and health care, and key livelihood resources, including land, physical infrastructure, or green spaces, is restricted (Yen et al. 2016, Flower et al. 2018).

Floods and windstorms have moderately affected communities in both locations. FGD participants revealed that because their villages are located in flat areas near natural lakes and canals, they are prone to two climate-related risks. Floods had often occurred during heavy rain, and water remained in the communities between a few hours and a week. This corresponds with literature findings highlighting the common impacts of urban flooding, with resulting water contamination from the sewage systems and poor household waste management (Kum et al. 2005, Flower and Fortnam 2015, Denney 2016). FGD participants further contended that because windstorm intensity was fairly strong, the rooftops of some frail houses had been damaged by this risk.

Table 2. Perceptions on the level of climate-related risks affecting urban communities.

\begin{tabular}{|c|c|c|c|c|c|c|}
\hline \multirow[t]{2}{*}{ Risks } & \multicolumn{2}{|c|}{$\begin{array}{c}\text { Saen Sokh } \\
(\mathrm{N}=207)\end{array}$} & \multicolumn{2}{|c|}{$\begin{array}{c}\text { Praek Phnov } \\
(\mathrm{N}=221)\end{array}$} & \multicolumn{2}{|c|}{$\begin{array}{c}\text { Overal } \\
(\mathrm{N}=428) \\
\end{array}$} \\
\hline & WAI & $\mathrm{OA}$ & WAI & $\mathrm{OA}$ & $P$ Value & $\mathrm{OA}$ \\
\hline Floods & 0.50 & $M$ & 0.52 & $\mathrm{M}$ & 0.51 & $\mathrm{M}$ \\
\hline Heat wave & 0.73 & $\mathrm{H}$ & 0.74 & $\mathrm{H}$ & 0.73 & $\mathrm{H}$ \\
\hline $\begin{array}{l}\text { Strong wind/ } \\
\text { storm }\end{array}$ & 0.48 & M & 0.44 & M & 0.46 & M \\
\hline Landslide & 0.21 & $\mathrm{~L}$ & 0.21 & $\mathrm{~L}$ & 0.21 & $\mathrm{~L}$ \\
\hline Thundering & 0.32 & $\mathrm{~L}$ & 0.31 & $\mathrm{~L}$ & 0.31 & $\mathrm{~L}$ \\
\hline $\begin{array}{l}\text { Vector-borne } \\
\text { diseases }\end{array}$ & 0.37 & $\mathrm{~L}$ & 0.41 & M & 0.39 & $\mathrm{~L}$ \\
\hline Fires & 0.23 & $\mathrm{~L}$ & 0.22 & $\mathrm{~L}$ & $0.23^{*}$ & $\mathrm{~L}$ \\
\hline
\end{tabular}

Notes: WAI indicates weight average index measured on a 5-point scale (very low $[\mathrm{VL}]=0.00-0.20$, low $[\mathrm{L}]=0.21-0.40$, moderate $[\mathrm{M}]=$ $0.41-0.60$, high $[\mathrm{H}]=0.61-0.80$, and very high $[\mathrm{VH}]=0.81-1.00)$. OA indicates overall assessment. Asterisk $(*)$ indicates significance at the 0.05 level.

Source: Nop and Thornton (unpublished data, from survey conducted in 2017).

Although the results from Table 2 indicate that vector-borne diseases are a low-level risk, the respondents perceived this differently. Respondents located along canals in newly established communities are highly susceptible to vector-borne diseases. These households have inadequate access to clean, potable water. Poor hygiene and sanitation conditions increase health risk, especially among children who are exposed to this poor living environment on a daily basis. The common health problems occurring in these urban communities include malaria, diarrhea, dengue fever, and respiratory diseases. FGD participants are aware of the health risks associated with "living in poor environmental zones [...] but we have no other choice because we do not have land to settle down." These findings correspond with the argument of Awuah (2018) highlighting that poor housing and environmental conditions, as well as infrastructure and services shortages, remain huge challenges for improving urban communities' adaptive capacity in African cities. The evidence tends to indicate that modern development is complicating community-level adaptation strategies to mitigate risks.

\section{The impacts of climate-related risks on urban livelihoods}

The independent $t$ test results (Table 3 ) reveal no significant differences in terms of respondents' perceptions of the level of impacts of climate-related risks on all attributes except "lose land" between both locations. Noticeably, respondents perceive that climate-related risks have moderately (1) damaged their houses and properties, (2) increased health problems, and (3) damaged local infrastructure. For FGD participants, these issues are predominantly caused by both floods and heat waves. FGD participants also highlight that for households on small plots of peri-urban and nonagricultural land, they have very limited access 
Table 3. Perceptions on the level of impacts of climate-related risks on urban livelihoods.

\begin{tabular}{|c|c|c|c|c|c|c|}
\hline \multirow[t]{2}{*}{ Attributes } & \multicolumn{2}{|c|}{ Saen Sokh $(\mathrm{N}=207)$} & \multicolumn{2}{|c|}{ Praek Phnov $(\mathrm{N}=221)$} & \multicolumn{2}{|c|}{ Overall $(\mathrm{N}=428)$} \\
\hline & WAI & $\mathrm{OA}$ & WAI & OA & $P$ Value & $\mathrm{OA}$ \\
\hline Lose lives & 0.24 & $\mathrm{~L}$ & 0.24 & $\mathrm{~L}$ & 0.24 & $\mathrm{~L}$ \\
\hline $\begin{array}{l}\text { Lose jobs or } \\
\text { businesses }\end{array}$ & 0.39 & $\mathrm{~L}$ & 0.40 & $\mathrm{~L}$ & 0.39 & $\mathrm{~L}$ \\
\hline $\begin{array}{l}\text { Damage house and } \\
\text { other properties }\end{array}$ & 0.46 & M & 0.44 & M & 0.45 & M \\
\hline $\begin{array}{l}\text { Health problem or } \\
\text { diseases }\end{array}$ & 0.53 & M & 0.52 & M & 0.53 & M \\
\hline Lose land & 0.22 & $\mathrm{~L}$ & 0.24 & $\mathrm{~L}$ & $0.23 *$ & $\mathrm{~L}$ \\
\hline $\begin{array}{l}\text { Damage } \\
\text { infrastructure }\end{array}$ & 0.53 & M & 0.51 & M & 0.52 & M \\
\hline School absence & 0.33 & $\mathrm{~L}$ & 0.35 & $\mathrm{~L}$ & 0.34 & $\mathrm{~L}$ \\
\hline $\begin{array}{l}\text { Damage } \\
\text { playground }\end{array}$ & 0.23 & $\mathrm{~L}$ & 0.23 & $\mathrm{~L}$ & 0.23 & $\mathrm{~L}$ \\
\hline $\begin{array}{l}\text { Damage water } \\
\text { sources }\end{array}$ & 0.38 & $\mathrm{~L}$ & 0.35 & $\mathrm{~L}$ & 0.36 & $\mathrm{~L}$ \\
\hline Damage crops/ & 0.27 & $\mathrm{~L}$ & 0.24 & $\mathrm{~L}$ & 0.25 & $\mathrm{~L}$ \\
\hline
\end{tabular}

Notes: WAI indicates weight average index measured on a 5-point scale (very low $[\mathrm{VL}]=0.00-0.20$, low $[\mathrm{L}]=0.21-0.40$, moderate $[\mathrm{M}]=0.41-0.60$, high $[\mathrm{H}]=0.61-0.80$, and very high $[\mathrm{VH}]=0.81-1.00)$. OA indicates overall assessment. Asterisk $(*)$ indicates significance at the 0.05 level.

Source: Nop and Thornton (unpublished data, from survey conducted in 2017).

to parks or playgrounds, which explains why these assets are not significantly affected by climate risks.

In a broad sense, this result is consistent with climate risks and disasters experienced by many ASEAN (Association of Southeast Asian Nations) cities, which have been catastrophic in terms of economic and social destruction and the loss of human life (Friend et al. 2015, Kumar 2015, Sarath Chandran et al. 2017). The increase of climate-related risks has brought about loss of livelihoods and incomes and increased expenditure in health care and property maintenance (STT 2009, Flower and Fortnam 2015). Our findings also reflect studies in environmental change in cases of health effects such as sanitation, infectious diseases, vector-borne diseases, or heatstroke as often encountered by urban poor communities in many Asian cities (Tyler et al. 2010, Flower et al. 2018).

\section{Adaptation mechanisms of urban communities}

Table 4 illustrates the respondents' perceptions on the levels of effectiveness of adaptation strategies of urban communities in responding to the risks of climate-related hazards. The independent $t$ test results of respondents' perceptions of coping strategies revealed "building higher footpaths/roads" and "upgrading/building higher houses" as two key strategies adopted by communities in both locations. These two strategies are perceived as moderately effective to prevent urban communities from potential risks. FGD participants proclaim that with higher houses, dwellers can protect their household property from flood damage, whereas with higher footpaths or roads, they can still walk and do small business activities during flooding. Urban dwellers have also temporarily moved from homes, constructed dikes, planted more trees, and migrated to other locations. These strategies were only slightly effective because of spatial constraints. There were isolated cases of peri-urban dwellers watering down their rooftops to reduce heat impacts. This result aligns with the findings of Mitchell et al. (2015) and Platt et al.
(2016) suggesting that adaptation mechanisms of urban poor communities in many developing countries are usually found to be ineffective because (1) they are located on marginal lands, in term of soil quality and landslide hazards; (2) they have poorquality materials and engineering for building construction; (3) they have limited access to information to prevent and/or recover quickly from shock and stress; and (4) they have limited capacity to reorganize and recover losses. The evidence reflects low transformability of urban communities because they tend to have limited innovation in designing more effective strategies to cope with risks with the absence of external assistance.

\section{Support in improving urban communities' adaptive capacity}

Type of support during disaster risks

Table 5 describes types of support that urban communities in both Khans have received during the exposure to climate-related problems as part of their recovery process. Two-thirds of respondents received increased health-care support from government or NGOs, whereas one-third expressed no increase. The chi-square test result reveals a significant difference $\left(\chi^{2}=\right.$ 12.585 , df $=1, P=0.000$ ) in health-care support between both study areas. Similarly, about $61 \%$ of respondents claimed to have been included in awareness raising for climate-related issues and problem solving processes. The chi-square test results reveal a significant difference in terms of perception of support between both locations $\left(\chi^{2}=9.732, \mathrm{df}=1, P=0.002\right)$. These communities tend to receive less support in other livelihood components such as food, shelter, home reconstruction, rescue and relief, and training on how to cope with risks.

\section{The degree of external support for urban communities}

Apart from ad hoc assistance from climate-related events, Table 6 reveals types of support offered to affected communities for livelihood assistance and resilience building. From WAI, communities have received moderate support in five sectors, 
Table 4. Perceptions on the level of effectiveness of strategies to cope with climate-related risks in urban communities.

\begin{tabular}{|c|c|c|c|c|c|c|}
\hline \multirow[t]{2}{*}{ Attributes } & \multicolumn{2}{|c|}{ Saen Sokh $(N=207)$} & \multicolumn{2}{|c|}{ Praek Phnov $(\mathrm{N}=221)$} & \multicolumn{2}{|c|}{ Overall $(\mathrm{N}=428)$} \\
\hline & WAI & $\mathrm{OA}$ & WAI & $\mathrm{OA}$ & $P$ Value & $\mathrm{OA}$ \\
\hline Temporarily move out of village & 0.30 & $\mathrm{~L}$ & 0.30 & $\mathrm{~L}$ & 0.30 & $\mathrm{~L}$ \\
\hline Build higher footpath/roads & 0.45 & M & 0.44 & M & 0.44 & M \\
\hline Build dikes & 0.27 & $\mathrm{~L}$ & 0.28 & $\mathrm{~L}$ & 0.27 & $\mathrm{~L}$ \\
\hline Upgrade/build higher houses & 0.52 & $\mathrm{M}$ & 0.54 & $\mathrm{M}$ & 0.53 & $\mathrm{M}$ \\
\hline Preserve and plant more trees & 0.40 & $\mathrm{~L}$ & 0.34 & $\mathrm{~L}$ & $0.37^{* * *}$ & $\mathrm{~L}$ \\
\hline Migrate to other areas & 0.22 & $\mathrm{~L}$ & 0.23 & $\mathrm{~L}$ & 0.22 & $\mathrm{~L}$ \\
\hline
\end{tabular}

Notes: WAI indicates weight average index measured on a 5-point scale (very low $[\mathrm{VL}]=0.00-0.20$, low $[\mathrm{L}]=0.21-0.40$, moderate $[\mathrm{M}]=0.41-0.60$, high $[\mathrm{H}]=0.61-0.80$, and very high $[\mathrm{VH}]=0.81-1.00)$. OA indicates overall assessment. Asterisks $(* * *)$ indicate significance at the 0.00 level.

Source: Nop and Thornton (unpublished data, from survey conducted in 2017).

Table 5. Perceptions on external support for affected communities.

\begin{tabular}{|c|c|c|c|c|c|c|}
\hline \multirow[t]{2}{*}{ Attributes } & & \multicolumn{2}{|c|}{ Name of Khan } & \multirow[t]{2}{*}{ Total } & \multirow[t]{2}{*}{$\%$} & \multirow[t]{2}{*}{$\chi^{2}$ Test Result } \\
\hline & & $\begin{array}{c}\text { Saen Sokh } \\
(\mathrm{N}=207)\end{array}$ & $\begin{array}{c}\text { Praek Phnov } \\
(\mathrm{N}=221)\end{array}$ & & & \\
\hline \multirow[t]{2}{*}{ Food items } & No & 146 & 173 & 319 & 75 & $\chi^{2}=3.381, \mathrm{df}=1, P=0.066$ \\
\hline & Yes & 61 & 48 & 109 & 25 & \\
\hline \multirow[t]{2}{*}{ Shelters } & No & 185 & 202 & 387 & 90 & $\chi^{2}=0.509, \mathrm{df}=1, P=0.476$ \\
\hline & Yes & 22 & 19 & 41 & 10 & \\
\hline \multirow{2}{*}{ Home reconstruction } & No & 184 & 209 & 393 & 92 & $\chi^{2}=4.594, \mathrm{df}=1, P=0.032^{*}$ \\
\hline & Yes & 23 & 12 & 35 & 8 & \\
\hline \multirow[t]{2}{*}{ Health care } & No & 88 & 58 & 146 & 34 & $\chi^{2}=12.585, \mathrm{df}=1, P=0.000^{* * *}$ \\
\hline & Yes & 119 & 163 & 282 & 66 & \\
\hline \multirow[t]{2}{*}{ Rescue and relief } & No & 197 & 215 & 412 & 96 & $\chi^{2}=1.330, \mathrm{df}=1, P=0.249$ \\
\hline & Yes & 10 & 6 & 16 & 4 & \\
\hline \multirow[t]{2}{*}{ Awareness raising } & No & 96 & 70 & 166 & 39 & $\chi^{2}=9.732, \mathrm{df}=1, P=0.002^{* *}$ \\
\hline & Yes & 111 & 151 & 262 & 61 & \\
\hline \multirow{2}{*}{$\begin{array}{l}\text { Trainings on disaster risk } \\
\text { reduction }\end{array}$} & No & 176 & 191 & 367 & 86 & $\chi^{2}=0.172, \mathrm{df}=1, P=0.679$ \\
\hline & Yes & 31 & 30 & 61 & 14 & \\
\hline
\end{tabular}

Note: Asterisks $\left(*, * *\right.$, and $\left.{ }^{* * *}\right)$ indicate significance at the $0.05,0.01$, and 0.00 levels, respectively.

Source: Nop and Thornton (unpublished data, from survey conducted in 2017).

including local infrastructure improvement, water resource management, health-care services, general education for children, and local environmental protection. The independent $t$ test results reveal no significant differences between both locations among these attributes, except "water resource management." Support in other sectors (Table 6) has been assessed as "low level."

Interviews reveal that despite the rapid increase of city investment projects during the last decade, the living conditions of urban poor communities remain unchanged because many dwellers remain living in informal and poor settlements, having limited income, and exposed to poor hygiene and sanitation. These results correspond with the World Bank (2018) report suggesting that the needs and challenges of the poor are being neglected in the process of modernizing Phnom Penh City. Respondents further indicate that if all these attributes were to be improved satisfactorily, communities could feel more secured and gain more confidence to swiftly respond and adapt to potential risks by themselves. They note that by having food security, better skills, and the availability of financing to start businesses, community members would be able to consume sufficient calories and build more family savings. Likewise, by upgrading local infrastructure, enhancing the local environment, or improving health-care services, urban dwellers could possibly lead healthier lives and better plan for long-term development of their families and communities.

Our evidence suggests that current climate-related risks moderately affect urban livelihoods, but because of limited mechanisms to minimize impacts, those risks seem to exacerbate the poor living conditions in informal urban areas. As discussed previously, although urban upgrading projects have been established, poor conditions, i.e., unsecured shelters and insufficient basic infrastructure and services, in informal areas have not improved. For instance, ineffective waste management systems exacerbate the effects of floods, causing serious health problems for urban poor communities. This reflects a limited capability of urban communities to cope with the disturbances (Meerow et al. 2016). 
Table 6. Perceptions on the level of external support for urban communities in improving their adaptive capacity.

\begin{tabular}{|c|c|c|c|c|c|c|}
\hline \multirow[t]{2}{*}{ Attributes } & \multicolumn{2}{|c|}{ Saen Sokh $(\mathrm{N}=207)$} & \multicolumn{2}{|c|}{ Praek Phnov $(\mathrm{N}=221)$} & \multicolumn{2}{|c|}{ Overall $(\mathrm{N}=428)$} \\
\hline & WAI & $\mathrm{OA}$ & WAI & $\mathrm{OA}$ & $P$ Value & $\mathrm{OA}$ \\
\hline Food security & 0.33 & $\mathrm{~L}$ & 0.30 & $\mathrm{~L}$ & 0.31 & $\mathrm{~L}$ \\
\hline $\begin{array}{l}\text { Skills building and } \\
\text { development }\end{array}$ & 0.31 & $\mathrm{~L}$ & 0.30 & $\mathrm{~L}$ & 0.31 & $\mathrm{~L}$ \\
\hline $\begin{array}{l}\text { Financial for } \\
\text { income activities }\end{array}$ & 0.28 & $\mathrm{~L}$ & 0.27 & $\mathrm{~L}$ & 0.27 & $\mathrm{~L}$ \\
\hline Health-care services & 0.59 & M & 0.59 & M & 0.59 & M \\
\hline $\begin{array}{l}\text { Education for } \\
\text { children }\end{array}$ & 0.55 & M & 0.55 & M & 0.55 & M \\
\hline Business expansion & 0.31 & $\mathrm{~L}$ & 0.28 & $\mathrm{~L}$ & $0.30 *$ & $\mathrm{~L}$ \\
\hline $\begin{array}{l}\text { Market for local } \\
\text { products }\end{array}$ & 0.33 & $\mathrm{~L}$ & 0.33 & $\mathrm{~L}$ & 0.33 & $\mathrm{~L}$ \\
\hline $\begin{array}{l}\text { Local infrastructure } \\
\text { development }\end{array}$ & 0.58 & M & 0.58 & M & 0.58 & M \\
\hline $\begin{array}{l}\text { Water resource } \\
\text { management }\end{array}$ & 0.61 & $\mathrm{H}$ & 0.53 & M & $0.57 * * *$ & M \\
\hline $\begin{array}{l}\text { Environmental } \\
\text { protection }\end{array}$ & 0.43 & M & 0.42 & M & 0.42 & M \\
\hline $\begin{array}{l}\text { Natural resource } \\
\text { management }\end{array}$ & 0.34 & $\mathrm{~L}$ & 0.34 & $\mathrm{~L}$ & 0.34 & $\mathrm{~L}$ \\
\hline $\begin{array}{l}\text { Disaster risk } \\
\text { management }\end{array}$ & 0.35 & $\mathrm{~L}$ & 0.31 & $\mathrm{~L}$ & $0.33 * * *$ & $\mathrm{~L}$ \\
\hline $\begin{array}{l}\text { Assistance during } \\
\text { high inflation }\end{array}$ & 0.28 & $\mathrm{~L}$ & 0.28 & $\mathrm{~L}$ & 0.28 & $\mathrm{~L}$ \\
\hline $\begin{array}{l}\text { Technical } \\
\text { develonment }\end{array}$ & 0.25 & $\mathrm{~L}$ & 0.24 & $\mathrm{~L}$ & 0.24 & $\mathrm{~L}$ \\
\hline
\end{tabular}

Notes: WAI indicates weight average index measured on a 5-point scale (very low $[\mathrm{VL}]=0.00-0.20$, low $[\mathrm{L}]=0.21-0.40$, moderate $[\mathrm{M}]=0.41-0.60$, high $[\mathrm{H}]=0.61-0.80$, and very high $[\mathrm{VH}]=0.81-1.00)$. OA indicates overall assessment. Asterisks $(*$ and $* * *)$ indicate significance at the 0.05 and 0.00 levels, respectively.

Source: Nop and Thornton (unpublished data, from survey conducted in 2017).

Main actors influencing communities' adaptive capacity

The majority of respondents $(86 \%)$, in both study areas, perceive that community-level adaptive capacity is determined by individual households, with others stating that government agencies $(11 \%)$ and NGOs $(3 \%)$ have supported their adaptive strategies. Respondents reveal that during the stage of preparing for and confronting disturbances, individual households have usually relied on their own capacities, unless the villages are under government or NGO project coverage, in which case the target beneficiaries could receive support. The research participants, however, view that the support is insufficient and fragmented and therefore unable to assist the community to improve in the long run. This corresponds with Joseph et al. (2013), who indicate that the adaptive capacity of communities is often formed through livelihood transitions and using available individual and community resources. Many respondents want to see a clear government mechanism for promoting the capacity and security of urban communities through legalizing informal settlements, provision of land certificates, improving basic infrastructure and services, and supporting income generation activities.

The evidence seems to reveal a divergence between the modernization premise and the actual outcomes of contemporary urban development processes. The rapid growth of private investments, especially in construction in Phnom Penh, appears to be influenced by economic models for modern urban development that reflect heavily critiqued ideas rooted in modernization theory and its more contemporary revisions (Inglehart 2014, Marsh 2014). The approach to urban development as influenced by state-driven efforts to modernize (Olds et al. 2002) appears to contradict policy statements for building urban resiliency. Consequently, the capacity of urban communities and state government to cope with shocks and stress remains limited.

\section{CONCLUSION}

We explored tensions related to the pursuit of modernizing cities in developing countries for both economic growth and urban resilience building. We found that urban upgrading as an approach to modernize has not improved the lives of the urban poor. Livelihoods remain confronted with the negative impacts of climate change, and, consequently, the urban poor suffer loss of life, property damage, and physical and mental health problems. From our review of the literature, the adaptive capacity of individuals or communities is often expected to be enhanced through modernization. In the city of Phnom Penh, we revealed that attempts by city officials to modernize have contributed to low adaptive capacity in informal settlements. Despite the presence of urban communities' adaptation strategies, these have been assessed by us as having "low effectiveness" because of insufficient household capacity and external support. Our findings identified the practice of loans as a household adaptation strategy in response to the loss of livelihoods and assets. This finding challenges the viewpoints of Jha et al. (2013), Marsh 
(2014), and Inglehart (2014) who propose that urban resilience can be strengthened through revitalized modernization concepts, influenced by neoliberalism. This is not to argue that urban upgrading is always negative. On the contrary, strategies that are inclusive of community input should be explored and applied in real practice. To reduce the impacts of climate-related hazards and enhance the adaptive capacity of urban residents, urban development processes should consider the following:

- Supporting urban poor communities with livelihood improvement programs through enhancing knowledge and expanding employment opportunities and market access for urban poor communities.

- Designing DRR programs based on the specific context of urban communities should be integrated into commune/ Sangkat investment plans, with active participation by communities and other key stakeholders in program planning, implementation, and monitoring.

The impacts of climate-related risks on human society are increasing, which is a key concern for sustainable urban development planning and policy making. In the context of Cambodia, our findings reflect wider trends of cities attempting to become more resilient cities. Although building urban resilience can be a daunting task, placing vulnerable communities at the center of the decision-making process can be an effective approach for building capacity and localized adaptation strategies.

${ }^{[1]}$ The main goals of urban upgrading are to provide secure land tenure in illegal and informal areas and to improve basic infrastructure and service delivery (Gulyani and Connors 2002).

Responses to this article can be read online at: http://www.ecologyandsociety.org/issues/responses. php/10860

\section{Acknowledgments:}

The authors greatly appreciate the valuable comments and suggestions from the editorial board and the anonymous referees. We also gratefully acknowledge Kvantai Ing, Sinal Hean, Pa Meas, Dara Moa, Cheat Un, Khammy Chhorn, Pounleu Tang, Vaty Thy, and Chankresna Choeun for assisting in the process of household surveys. This study has benefited from funding from the University of New South Wales (UNSW) Ph.D. Studentship. The work was conducted under approval from the Human Research Ethics Advisory Panel, UNSW Canberra.

\section{LITERATURE CITED}

Awuah, K. G. B. 2018. Urban development and governance in Nigeria: challenges, opportunities and policy direction. International Development Planning Review 40:27-49. https://doi. org/10.3828/idpr.2018.1

Bidandi, F., and J. J. Williams. 2017. The challenges facing urbanisation processes in Kampala. Urban Forum 28:235-249. https://doi.org/10.1007/s12132-017-9311-6
Birkmann, J., and K. von Teichman. 2010. Integrating disaster risk reduction and climate change adaptation: key challengesscales, knowledge, and norms. Sustainability Science 5:171-184. https://doi.org/10.1007/s11625-010-0108-y

Brickell, K. 2014. "The whole world is watching": intimate geopolitics of forced eviction and women's activism in Cambodia. Annals of the Association of American Geographers 104:1256-1272. https://doi.org/10.1080/00045608.2014.944452

Brickell, K., M. F. Arrigoitia, and A. Vasudevan. 2017. Geographies of forced eviction: dispossession, violence, resistance. Pages 1-23 in K. Brickell, M. F. Arrigoitia, and A. Vasudevan, editors. Geographies of forced eviction. Palgrave Macmillan, London, UK. https://doi.org/10.1057/978-1-137-51127-0_1

Casolo, J., and S. Doshi. 2013. Domesticated dispossessions? Towards a transnational feminist geopolitics of development. Geopolitics 418(4):800-834. https://doi.org/10.1080/14650045.2013.811644

Coaffee, J., and P. Lee. 2016. Urban resilience: planning for risk, crisis and uncertainty. Palgrave Macmillan, London, UK.

Connell, J. 2015. Is "good" resettlement policy unimplementable? Learning from advocacy in Cambodia. Development in Practice 25:655-672. https://doi.org/10.1080/09614524.2015.1050998

Connell, J., and J. Connell. 2016. Development-induced displacement, adaptation and mobility in Cambodia. Migration and Development 5:413-430. https://doi.org/10.1080/21632324.2$\underline{014.984900}$

Corbetta, P. 2003. Social research: theory, methods and techniques. Sage, London, UK.

Councils of Snagkat Khmuonh. 2016. Statistic of population of Sangkat Khmuonh in 2016. Sangkat Khmuonh, Phnom Penh, Cambodia.

Councils of Snagkat Kouk Roka. 2016. Statistic of population of Sangkat Kouk Roka in 2016. Sangkat Kouk Roka, Phnom Penh, Cambodia.

Davis, M. 2006. Planet of slums. New Perspectives Quarterly 23:6-11. https://doi.org/10.1111/j.1540-5842.2006.00797.x

Davoudi, S., K. Shaw, L. J. Haider, A. E. Quinlan, G. D. Peterson, C. Wilkinson, H. Fünfgeld, D. McEvoy, L. Porter, and S. Davoudi. 2012. Resilience: a bridging concept or a dead end? "Reframing" resilience: challenges for planning theory and practice interacting traps: resilience assessment of a pasture management system in northern Afghanistan. Urban resilience: what does it mean in planning practice? Resilience as a useful concept for climate change adaptation? The politics of resilience for planning: a cautionary note. Planning Theory \& Practice 13:299-333. https:// doi.org/10.1080/14649357.2012.677124

Denney, L. 2016. Reforming solid waste management in Phnom Penh. Working Politically in Practice Series, Case Study No. 8. The Asia Foundation, San Francisco, California, USA.

Desouza, K. C., and T. H. Flanery. 2013. Designing, planning, and managing resilient cities: a conceptual framework. Cities 35:89-99. https://doi.org/10.1016/j.cities.2013.06.003

Diepart, J.-C., W. Koditek, T. Hänert, F. Rock, S. Pen, and B. Meng. 2016. Introduction to the Cambodian spatial planning 
system. Spatial Planning Series No. 1. Ministry of Land Management, Urban Planning and Construction, Phnom Penh, Cambodia.

Di Feliciantonio, C. 2016. Subjectification in times of indebtedness and neoliberal/austerity urbanism. Antipode: A Radical Journal of Geography 48:1206-1227. https://doi. org/10.1111/anti.12243

Flower, B., and M. Fortnam. 2015. Urbanising disaster risk: vulnerability of the urban poor in Cambodia to flooding and other hazards. People in Need, Phnom Penh, Cambodia.

Flower, B., M. Fortnam, L. Kol, P. Sasin, and R. G. Wood. 2018. Using participatory methods to uncover interacting urban risks: a case study of three informal settlements in Phnom Penh, Cambodia. Environment and Urbanization 30:301-316.https:// doi.org/10.1177/0956247817735481

Friend, R., J. Henceroth, S. Reed, J. Jarvie, and P. Thinphanga. 2013. How is building resilience different from all other programs? Experience from promoting urban climate change resilience. Institute for Social and Environmental Transition-International, Boulder, Colorado, USA.

Friend, R. M., P. Thinphanga, K. MacClune, J. Henceroth, P. V. G. Tran, and T. P. Nghiem. 2015. Urban transformations and changing patterns of local risk: lessons from the Mekong Region. International Journal of Disaster Resilience in the Built Environment 6:30-43. https://doi.org/10.1108/IJDRBE-08-2014-0061

Guild, R., and I. Matsumoto. 2013. Moving from risk to resilience: sustainable urban development in the Pacific. Asian Development Bank, Manila, Philippines.

Gulyani, S., and G. Connors. 2002. Urban upgrading in Africa: a summary of rapid assessments in ten countries. Africa Infrastructure Department, The World Bank, Washington, D.C., USA. [online] URL: http://web.mit.edu/urbanupgrading/ upgrading/case-examples/overview-africa/country-assessments/ download/10-CountrySummary.pdf

Hassan, A. M., and H. Lee. 2015. Toward the sustainable development of urban areas: an overview of global trends in trials and policies. Land Use Policy 48:199-212. https://doi.org/10.1016/ j.landusepol.2015.04.029

Hobson, K., and N. Lynch. 2018. Ecological modernization, techno-politics and social life cycle assessment: a view from human geography. International Journal of Life Cycle Assessment 23:456-463. https://doi.org/10.1007/s11367-015-1005-5

Inderberg, T. H., S. Eriksen, K. O’Brien, and L. Sygna. 2014. Climate change adaptation and development: transforming paradigms and practices. Routledge, London, UK. https://doi. org/10.4324/9781315774657

Inglehart, M. R. 2014. Pushing the envelope - analyzing the impact of values. Pages xix-xxv in R. J. Dalton and C. Welzel, editors. The civic culture transformed: from allegiant to assertive citizens. Cambridge University Press, New York, New York, USA.

Jabareen, Y. 2015. City planning deficiencies \& climate change the situation in developed and developing cities. Geoforum 63:40-43. https://doi.org/10.1016/j.geoforum.2015.05.017
Jänicke, M. 2008. Ecological modernisation: new perspectives. Journal of Cleaner Production 16:557-565. https://doi. org/10.1016/j.jclepro.2007.02.011

Japan International Cooperation Agency (JICA). 2014. The project for comprehensive urban transport plan in Phnom Penh capital city (PPUTMP). JICA, Phnom Penh, Cambodia.

Jha, A. K., T. W. Miner, and Z. Stanton-Geddes. 2013. Building urban resilience: principles, tools, and practice. The World Bank, Washington, D.C., USA. https://doi.org/10.1596/978-0-8213-8865-5

Joseph, V., A. Thornton, S. Pearson, and D. Paull. 2013. Occupational transitions in three coastal villages in Central Java, Indonesia, in the context of sea level rise: a case study. Natural Hazards 69:675-694. https://doi.org/10.1007/s11069-013-0735-6

Kilminster, R. 2007. Modernizing. Pages 43-61 in S. Matthewman, C. L. West-Newman, and B. Curtis, editors. Being sociological. Palgrave Macmillan, New York, New York, USA.

Kim, K.-D. 2017. Selective modernization and alternative modernities: in search of an alternative theory. Pages 77-123 in Alternative discourses on modernization and development. Palgrave Macmillan, Singapore, Singapore, Singapore.

Kum, V., A. Sharp, and N. Harnpornchai. 2005. Improving the solid waste management in Phnom Penh city: a strategic approach. Waste Management 25:101-109. https://doi.org/10.1016/ j.wasman.2004.09.004

Kumar, S. 2015. Engendering liveable low-carbon smart cities in ASEAN as an inclusive green growth model and opportunities for regional cooperation. ERIA Discussion Paper Series, ERIADP-2015-57. Economic Research Institute for ASEAN and East Asia (ERIA), Jakarta, Indonesia.

Liao, K. 2012. A theory on urban resilience to floods-a basis for alternative planning practices. Ecology and Society 17(4):48. https://doi.org/10.5751/ES-05231-170448

Lockie, S. 2015. Emergent themes? A year in the life of Environmental Sociology. Environmental Sociology 1:237-240. https://doi.org/10.1080/23251042.2015.1125610

Marsh, R. M. 2014. Modernization theory, then and now. Comparative Sociology 13:261-283. https://doi.org/10.1163/15691330-12341311

McFarlane, C. 2012. The entrepreneurial slum: civil society, mobility and the co-production of urban development. Urban Studies 49:2795-2816. https://doi.org/10.1177/0042098012452460

McGill, R. 2018. Making towns work: Habitat III - what relevance? Planning Theory \& Practice 19:140-148. https://doi. org/10.1080/14649357.2017.1369237

McMichael, P. 2012. Development and social change: a global perspective. Sage, Thousand Oaks, California, USA.

Meerow, S., J. P. Newell, and M. Stults. 2016. Defining urban resilience: a review. Landscape and Urban Planning 147:38-49. https://doi.org/10.1016/j.landurbplan.2015.11.011

Mehmood, A. 2016. Of resilient places: planning for urban resilience. European Planning Studies 24:407-419. https://doi. org/10.1080/09654313.2015.1082980 
Mgbako, C., R. E. Gao, E. Joynes, A. Cave, and J. Mikhailevich. 2010. Forced eviction and resettlement in Cambodia: case studies from Phnom Penh. Washington University Global Studies Law Review 9:39.

Mitchell, D., S. Enemark, and P. van der Molen. 2015. Climate resilient urban development: why responsible land governance is important. Land Use Policy 48:190-198. https://doi.org/10.1016/ j.landusepol.2015.05.026

National Council for Sustainable Development (NCSD), Royal Government of Cambodia, Phnom Penh Capital Hall, Global Green Growth Institute, and International Centre for Environmental Management. 2016. Phnom Penh Green City Strategic Plan 2016-2025. NCSD, Phnom Penh, Cambodia.

Neef, A., and J. Singer. 2015. Development-induced displacement in Asia: conflicts, risks, and resilience. Development in Practice 25:601-611. https://doi.org/10.1080/09614524.2015.1052374

NGO Forum on Cambodia. 2014. Statistical analysis of land disputes in Cambodia, 2013. NGO Forum on Cambodia, Phnom Penh, Cambodia.

Olds, K., T. Bunnell, and S. Leckie. 2002. Forced evictions in tropical cities: an introduction. Singapore Journal of Tropical Geography 23:247-251. https://doi.org/10.1111/1467-9493.00129

Phillips, N. 2011. Globalisation and development. Pages 416-449 in J. Ravenhill, editor. Global political economy. Oxford University Press, Oxford, UK.

Pickles, J., and A. Smith. 2005. Theorizing transition: the political economy of post-communist transformations. Routledge, London, UK. https://doi.org/10.4324/9780203982907

Platt, S., D. Brown, and M. Hughes. 2016. Measuring resilience and recovery. International Journal of Disaster Risk Reduction 19:447-460. https://doi.org/10.1016/j.ijdrr.2016.05.006

Sahmakum Teang Tnaut (STT). 2009. The 8 Khan Survey: urban poor settlements in Phnom Penh. STT, Phnom Penh, Cambodia.

Sahmakum Teang Tnaut (STT). 2016. Promises kept? A study on the development 77 eviction sites in Phnom Penh. STT, Phnom Penh, Cambodia.

Sahmakum Teang Tnaut (STT). 2018. The Phnom Penh Survey: a study on urban poor settlement in Phnom Penh. STT, Phnom Penh, Cambodia.

Sandelowski, M. 2000. Combining qualitative and quantitative sampling, data collection, and analysis techniques in mixedmethods studies. Research in Nursing \& Health 23:246-255. https:// doi.org/10.1002/1098-240X(200006)23:3\%3C246::AID-NUR9\% 3E3.0.CO;2-H

Sarath Chandran, M. A., A. V. M. Subba Rao, V. M. Sandeep, V. P. Pramod, P. Pani, V. U. M. Rao, V. Visha Kumari, and C. Srinivasa Rao. 2017. Indian summer heat wave of 2015: a biometeorological analysis using half hourly automatic weather station data with special reference to Andhra Pradesh. International Journal of Biometeorology 61:1063-1072. https:// doi.org/10.1007/s00484-016-1286-9

Sayan, R. C. 2017. Urban/rural division in environmental justice frameworks: revealing modernity-urbanisation nexus in Turkey's small-scale hydropower development. Local Environment: The International Journal of Justice and Sustainability 22:1510-1525. https://doi.org/10.1080/13549839.2017.1368465

Trac, T. S. 2015. Smart city master plan of Phnom Penh. Sustainable Urban Transport Workshop, Danag, Vietnam.

Tulumello, S. 2016. Reconsidering neoliberal urban planning in times of crisis: urban regeneration policy in a "dense" space in Lisbon. Urban Geography 37:117-140. https://doi. org/10.1080/02723638.2015.1056605

Tyler, S., S. O. Reed, K. MacClune, and S. Chopde. 2010. Planning for urban climate resilience: framework and examples from the Asian Cities Climate Change Resilience Network (ACCCRN). Climate Resilience in Concept and Practice Working Paper Series. Institute for Social and Environmental Transition, Boulder, Colorado, USA.

United Nations. 2014. World urbanization prospects: the 2014 revision - highlights. Statistical Papers - United Nations (Ser. A), Population and Vital Statistics Report. United Nations, New York, New York, USA. https://doi.org/10.18356/527e5125-en

United Nations. 2017. Sustainable Development Goals: 17 goals to transform our world. United Nations, New York, New York, USA. [online] URL: https://www.un.org/sustainabledevelopment/

United Nations Human Settlements Programme (UN Habitat). 2016. Urbanization and development: emerging futures. UN Habitat, Nairobi, Kenya.

Walliman, N. 2015. Social research methods: the essentials. Sage, Los Angeles, California, USA.

Willis, K. 2011. Theories and practices of development. Second edition. Routledge, London, UK. https://doi.org/10.4324/9780203844182

The World Bank. 2011. Guide to climate change adaptation in cities. International Bank for Reconstruction and Development/ The World Bank, Washington, D.C., USA. https://doi. org/10.1596/27396

The World Bank. 2018. Urban development in Phnom Penh. The World Bank, Phnom Penh, Cambodia.

Yen, Y., Z. Wang, Y. Shi, and B. Soeung. 2016. An assessment of the knowledge and demand of young residents regarding the ecological services of urban green spaces in Phnom Penh, Cambodia. Sustainability 8:523. https://doi.org/10.3390/su8060523

Zheng, Y., and K. Deng. 2018. Conundrum with distorted urbanisation. Pages 87-112 in State failure and distorted urbanisation in post-Mao's China, 1993-2012. Palgrave Pivot, Cham, Switzerland. https://doi.org/10.1007/978-3-319-92168-6 5 